\title{
برنامهج مقتزح للتدريب الميداني للطالبات / المعلمات بشعبة الاقتصاد المنزلي و أثره على الأداء و طلب المساعدة *
}

إعلاد

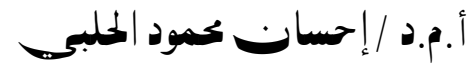

أستاذ مناهـج و طريق التدريس المساعد

بكلية التربية النوعية - جامعة المنصورة

غادة عبد الملك

باحث دكتوراه

\author{
أ. أه / إبراهيم إبراهيه أحمد \\ أستاذ عله النفس التربوي \\ و عميد كلية التربية النوعية - جامعة المنصورة \\ ه. / عاصم البحيركي ليوسف \\ مدرس مـناهـج و طرق التدريس \\ بكلية التربية النوعية - جامعة المنصورة
}

مجلة بحوث التربية النوعية ـ جامعة المنصورة

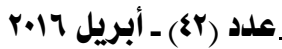

“ بحث مستل من رسالة دكتوراه 


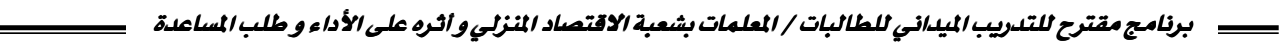




\section{برناهج هقتزح للتدريب الميداني للطالبات / المهلمات}

\section{بشعبة الاقتصاد المنزلي و أثره على الأداء و طلب المساعدة}

إعداد

$$
\begin{aligned}
& \text { أ.م .د / إحسازممود الحلبيـ** } \\
& \text { غادة عبد الملك }
\end{aligned}
$$

$$
\begin{aligned}
& \text { أ . د / إبراهيم إبراهيم/أحمد * } \\
& \text { *** } \\
& \text { د. / عاصم البحيريوسف }
\end{aligned}
$$

\section{هذف البحث}

1) فحص الادبيات والدراسات السـابقة (العربية والاجنبية) ذات الصلة بمتغيرات البحث

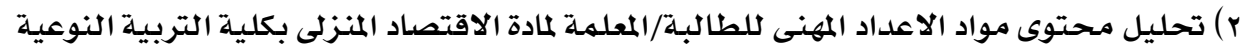

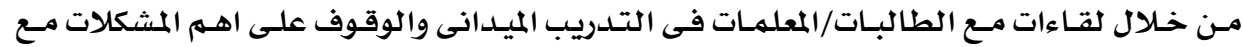

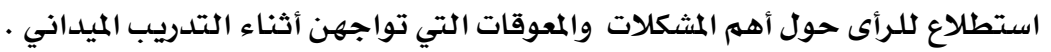

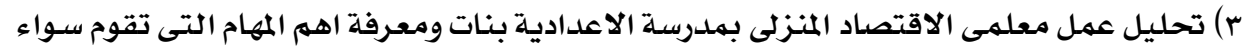

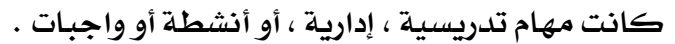

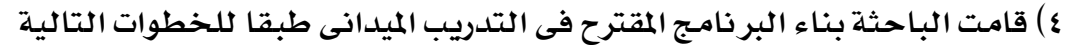

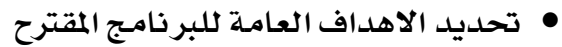

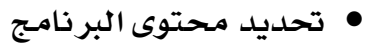

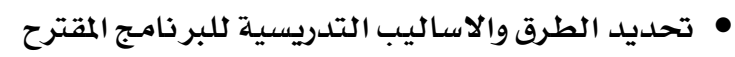

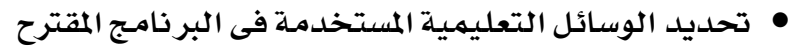

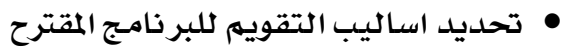

$$
\begin{aligned}
& \text { • • إعداد الخطة الزمنية . }
\end{aligned}
$$

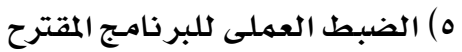

قامـت الباحثة بعـرض البر نـامج المقترح على مجموعـة مـن المحكمـين المتخصصين للتأكس

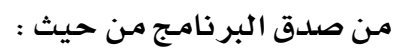

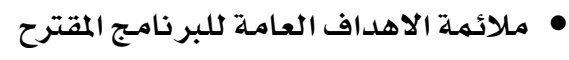

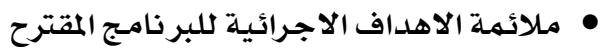

$$
\begin{aligned}
& \text { • ملائمسة محتوى البر نامهاج }
\end{aligned}
$$

* أستاذ علهم النفس التربوي و عميد كلية التربية النوعية - جامعة المنصورة

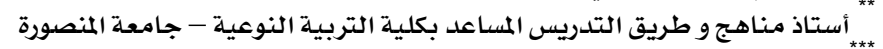

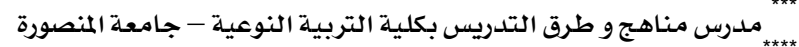
باحث دكتوراه 
בب برنامج مقترح للتدريب الميداني للطالبات / المعلمات بشعبة الاقتصاد المنزلبي واثره على الأداء وطلب المساعلة =

$$
\text { • ملائمسة الطرق والاساليب التدريسية للبرنامجر المقترح }
$$

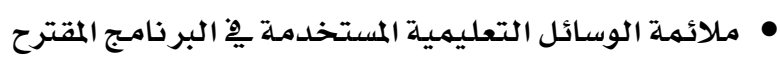

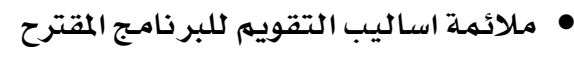

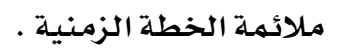

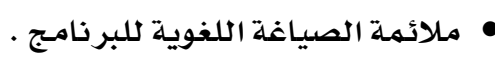

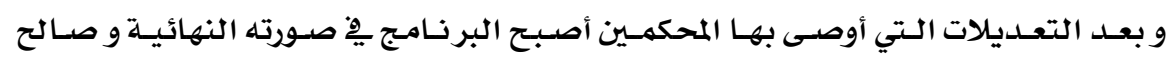

$$
\text { كلتطبيق · اعداد ادوات البحث }
$$

قامت الباحثة ببناء الأدوات اللازمـة لتحقيق أهداف البحث و ضبطها علمياً

مقد مهة البحث :

يعتبر المعلم من أهم عناصـر تحقيق أهداف السياسـات التعليميـة التي يرسهها و يخططها

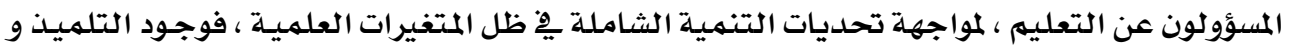

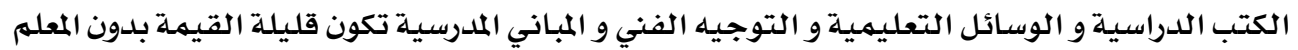

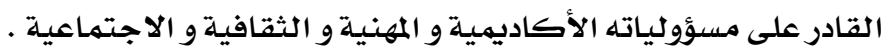

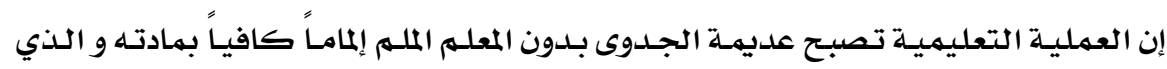

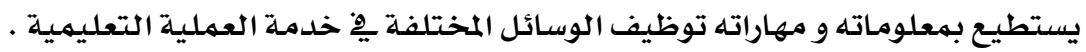

و يلتقى طلاب كليّات التربية و التربية النوعية خلال اعدادهم الوظيفي مـن مـواد وخبرات

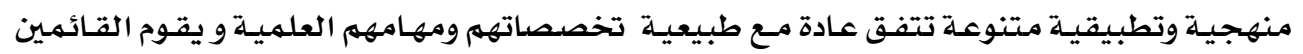

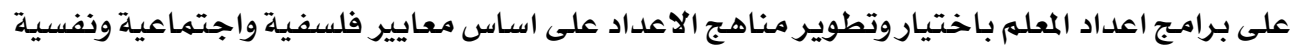

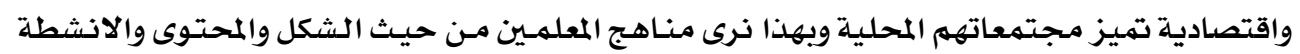

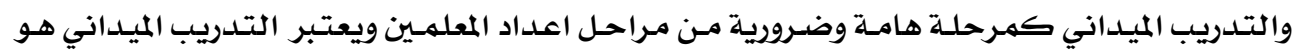

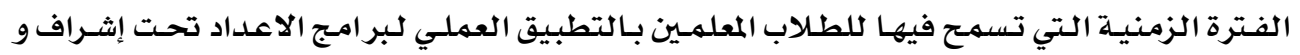

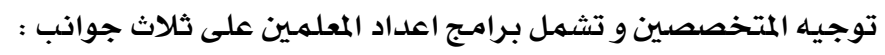

• الإعداد الثقايِّ و يشمل كل ما يحيط بيئة المعلم من معارف و معلومات و مفاهيهم .

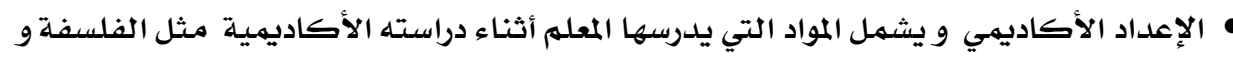

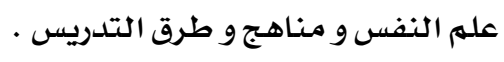

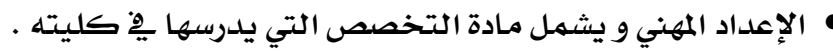

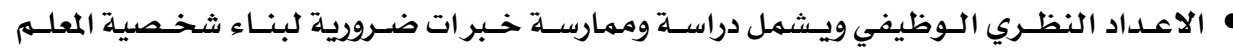

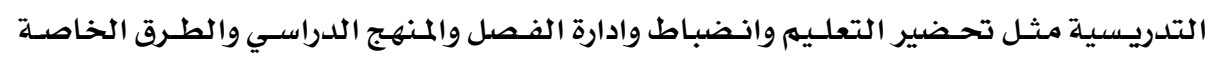

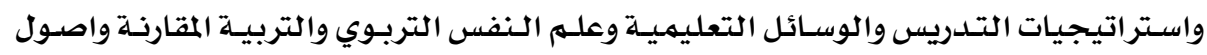

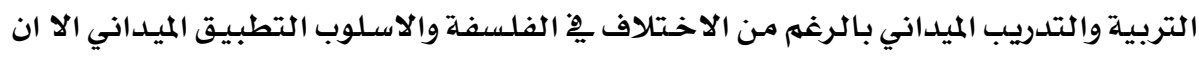


هناك اتفاقا وظيفيا عامـا على اساسيات التدريب الميداني ِِّ منـاهج اعداد المعلمـين وضـروريتها

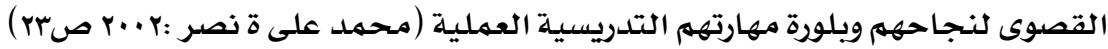
ومهما يكسن فان التـدريب الميداني أيا كانت الصيغة التطبيقيـة والتنظيميـة التي تتخـذها

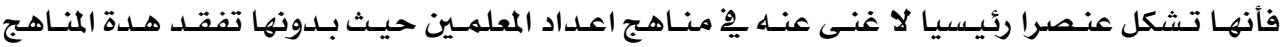

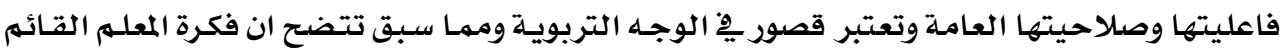

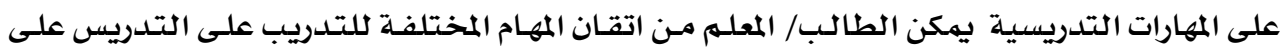

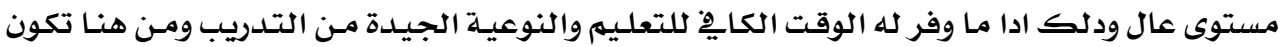

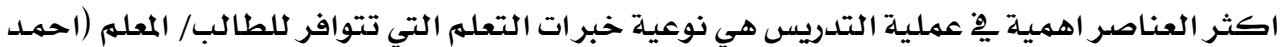

$$
\text { رجب الكلزة:1991 ص • •9 ) ) }
$$

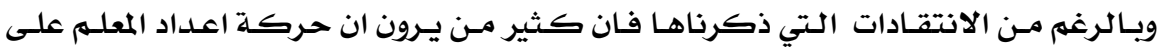

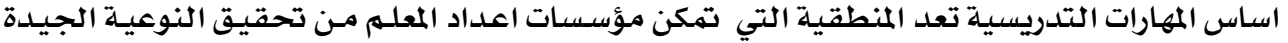

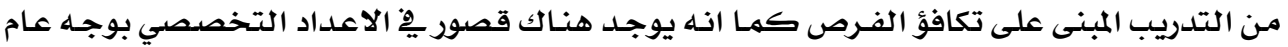

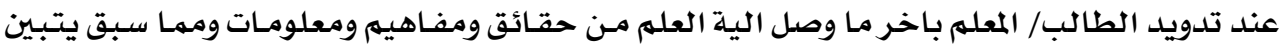

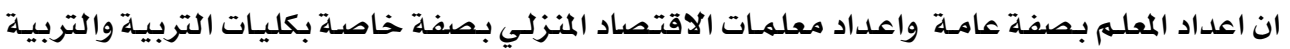

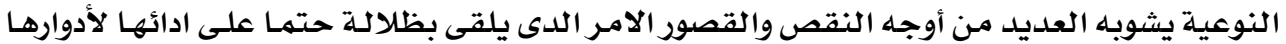

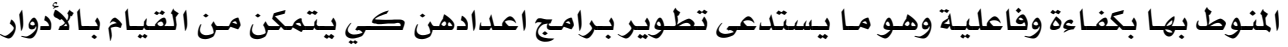

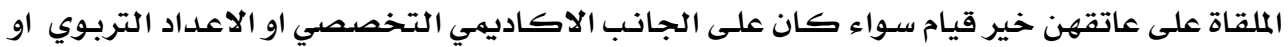

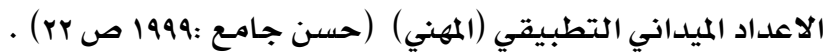
ونظرا لهدا القصور الملحوظ يِّ مجال اعداد المعلهم مما يؤثر سلبا على الطالب /المعلهم اثنـاء

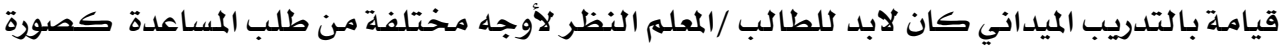

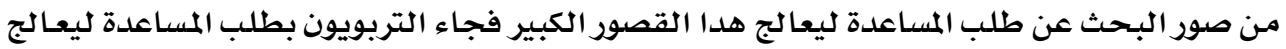

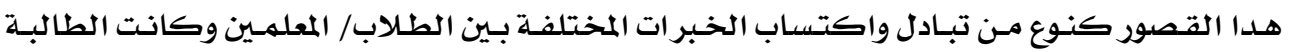

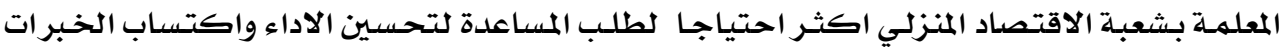

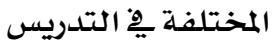

هشكلة البصث

فمن خلال دراسة الباحثة يٌْ مرحلة البكالوريوس وجود السلبيات فى :

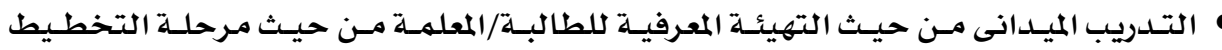

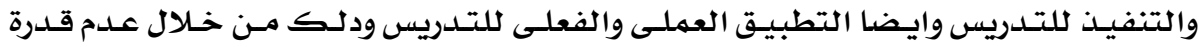

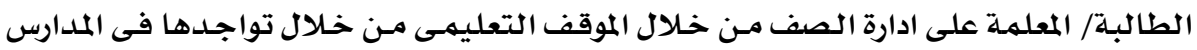

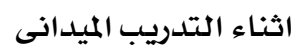

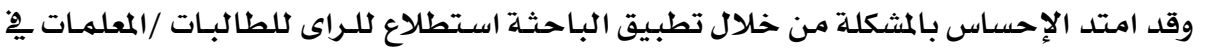

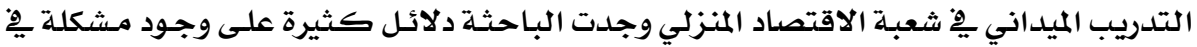




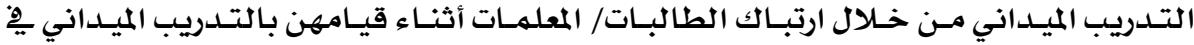

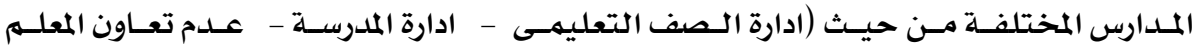

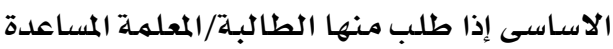

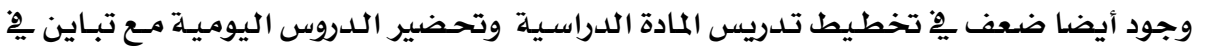

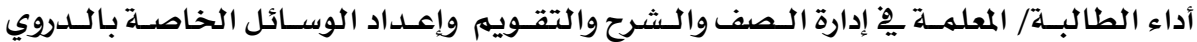

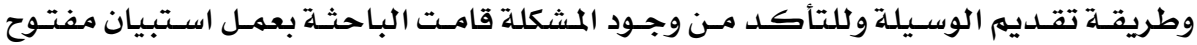

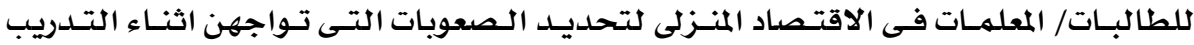

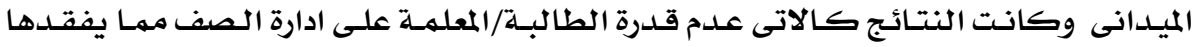

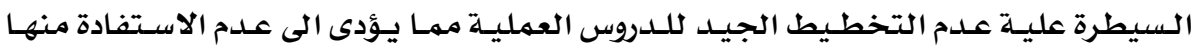

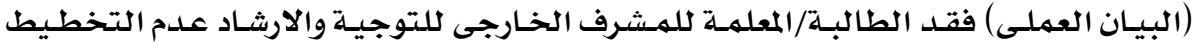

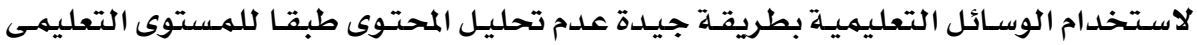

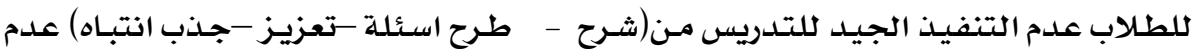

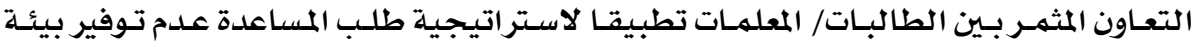

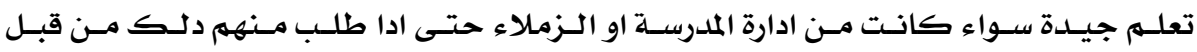
الطالبات/ المعلمات

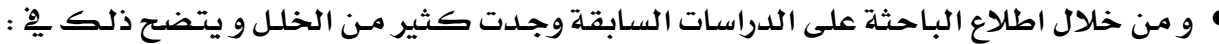

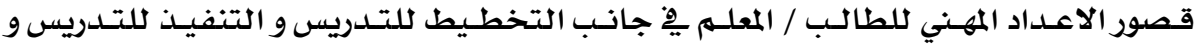

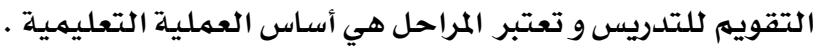

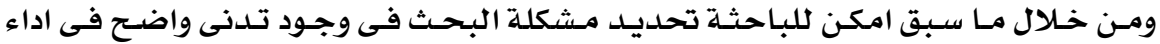

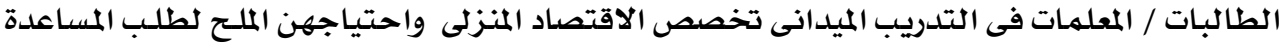

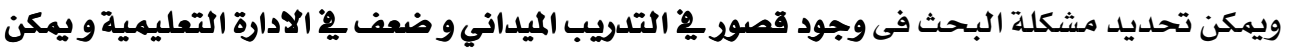

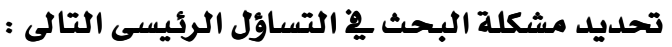
ما اثر برنامجج مقترح فى التدريب الميدانى للطالبات/المعلمات بشعبة الاقتصاد المنزئى على ولى

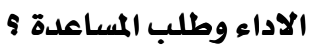

\section{و يتفرع منه التساؤلات التالية :-}

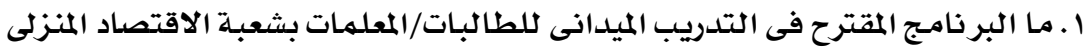

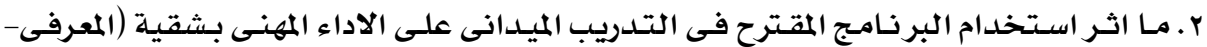
المهارىى)

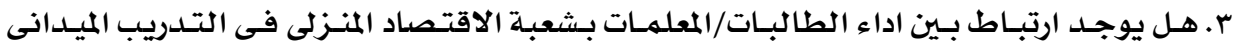

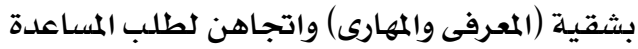




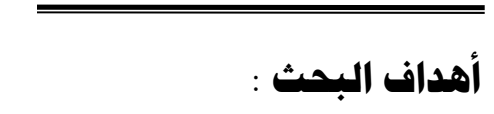

$$
\text { يهدف البحث الحالي لما يلى : }
$$

ا ـ اعداد برنـامج مقترح في التـدريب الميدانى للطالبـات /المعلمـات بشعبـة الاقتصـاد المنزلى بكليـة

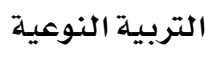

r . معرفة اهميـة طلب المسـاعدة في التنبؤ بالمخرجـات المهنيـة الجيدة للطالبـات/المعلمـات بشعبـة

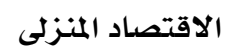

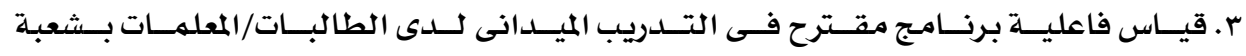

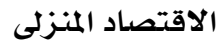

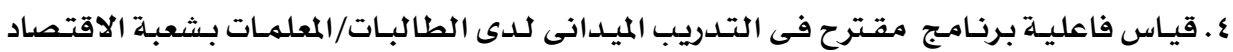

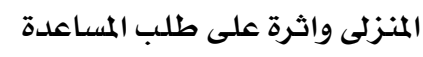

$$
\text { تكمن اهمية البحث الحالى فى : }
$$

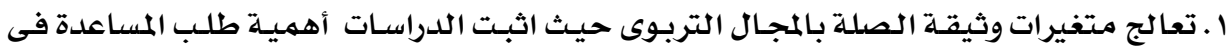

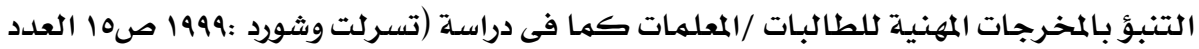

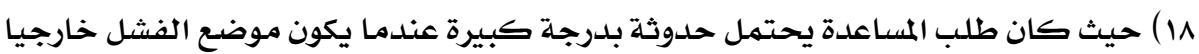

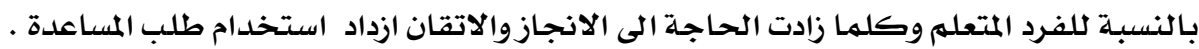

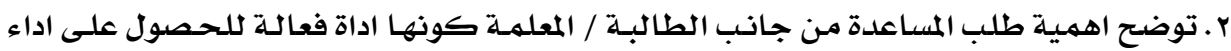

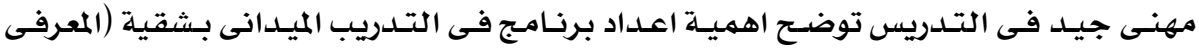

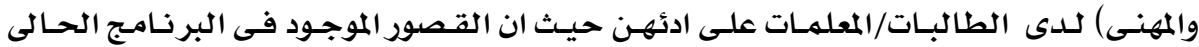

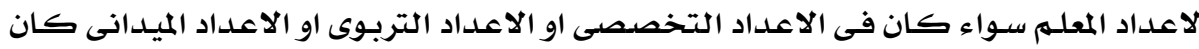

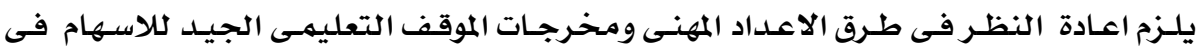
تحقيق عملية تعليمية افضل

\section{:

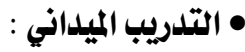

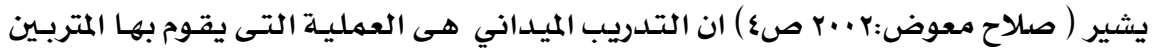

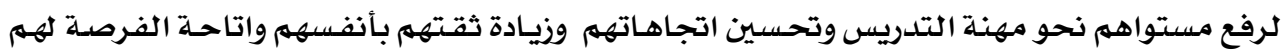

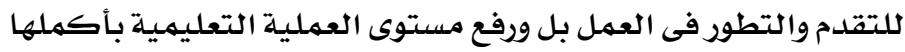

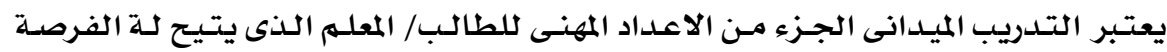

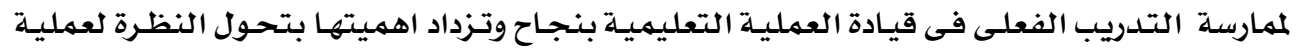

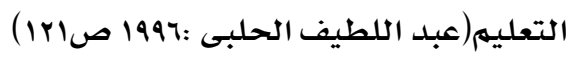


ويعد التدريب الميدانى خطوة هامـة فى عمليـة اعداد المعلهم ويقـصد بـه بــا انخـراط طـلاب المستويـات قبل النهائية بكليات التربية والتربية النوعيـة فى تدريب ميدانى فى الواقع الحقيقى بهدف التـدريب على مهنـة التـدريس التعـرف على مـاتنطوى عليـة هـذة المهنـة مـن وظـائف وادوار ومسستويـات

وذلك من خلال معايشـة الطالب للواقع التربوى والتعليهى (مها ابراهيه بسيونى :ج . . ص صاب) . ويُعـرف اجرائيـا بأنه الأداء التدريسسي الـذي ينطـوي على سـلوك معـين يهـن ملاحظتهـ و معرفة نائجهـ مـن خلال مـراحل التدريس ( التخطيط و الاعداد و التنفيذ و التقويهم ) للتدريس لمعرفة

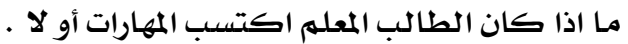
•

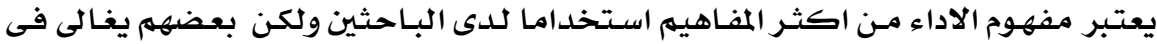
استعماله مها يشعر الآخرين باللبس فى فهمها وسنـحاول توضيح هذا المفهوم من خلال معناة اللغوي والاهطلاحي

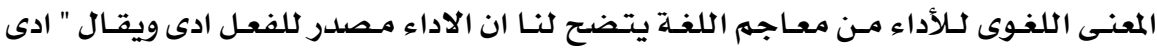

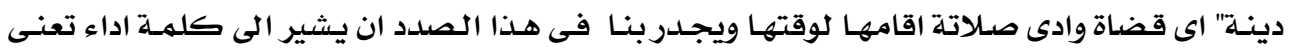
اجـراء تنفيـذي لأى شـى او عزف وضـرب على الـة موسـيقية ويسشير ايـضا ان الاداء اداء مهـارة والقـدرة

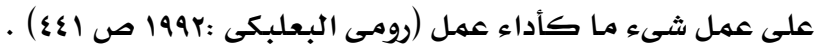
تعددت التعريفات لمفهوم الاداء وتذكر منها تعريف (جـود : 1990 اصه00) انه الانجـاز الفعلى او الحقيقـى المعـروف للقـــرات الفكريسة الكامنــة ويـذهب بعـض التربـويـين الى ان الاداء هــو الـسلوك الملاحظ فى موقف معين وتعلهم يستـدل عليـة مسن مـلاحظلة اداء الفـرد وكذلك يقصد بـالأداء تنفيــ الدروس ويتطلب من المعلم ريط موضوع الدرس بـالواقع الاجتهـاعي للطلاب واستخحدام طرق تـريس متتنوعة واستخدلام الوسـائل التعليميلة المناسبـة وربط المادة العلميلة بهشكلات الطلاب اليوميـة وتعميقق

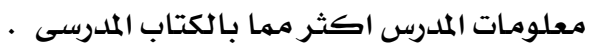
ويعرف اجرائيا بأنهم الجزء التدريب الميدانى :

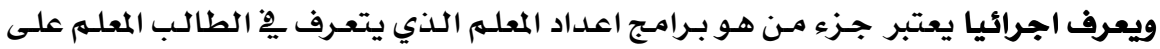
واقـع الحيـاة العلميـة للتـدريس وتحفيـز قدراتـــ للقيـام بـالادوار المختلفـة لمهنـة التـدريس و تتضهن

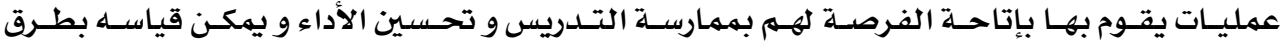


ان طلب المساعدة سلوك فعال لحل المشكلات التى يواجههـا الفـرد وتحث على تر بيـه الاولاد

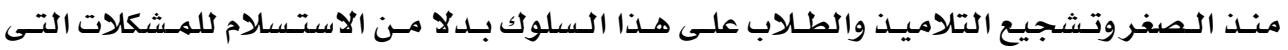

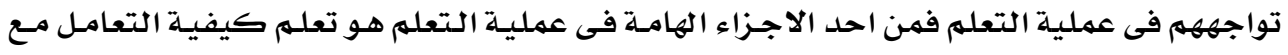

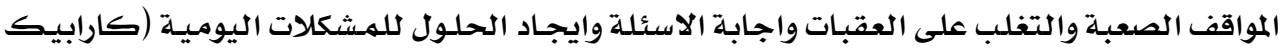

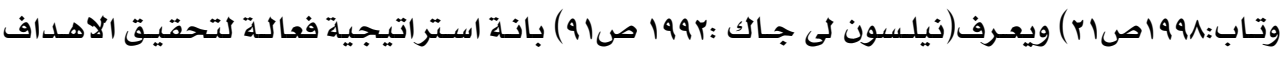

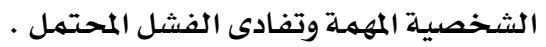

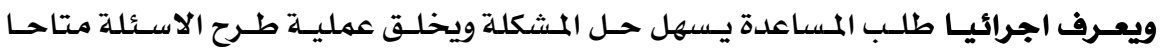

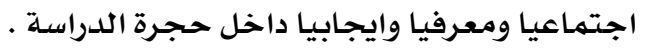

$$
\text { حدود البحث : يقتصر البحث الحمثيا وايجابيا داخلى مايلى : }
$$

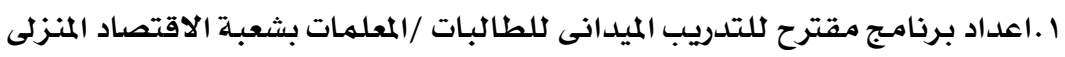

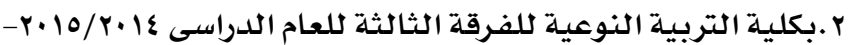

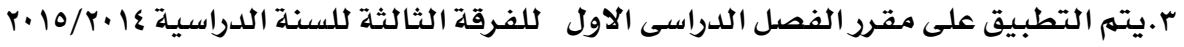

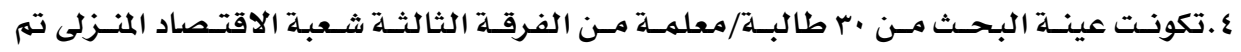

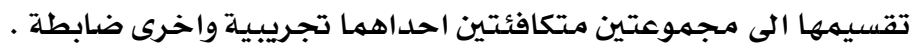

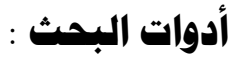

1. اعداد برنامج مقترح للتدريب الميداني للطالبات/المعلمات بشعبة الاقتصاد المنزلي اعداد الباحثة

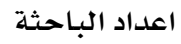
r r r r r اختبار تحصيلي اعداد الباحثة اعداحثة r. r. اختبار مواقف تعليمية اعداد الباحثة اعدادئ ع. مقياس سلوك طلب المساعدة

هنهج البحث : مقيان

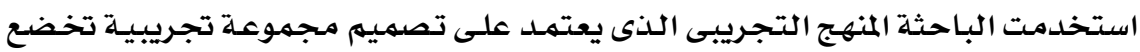

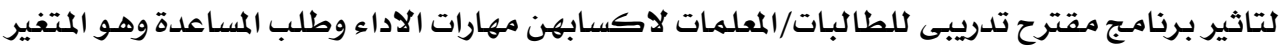

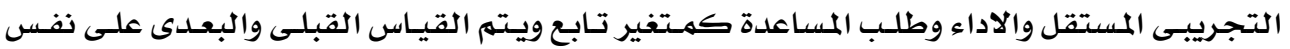
المجموعة لدراسة التغير الحادث المبن 


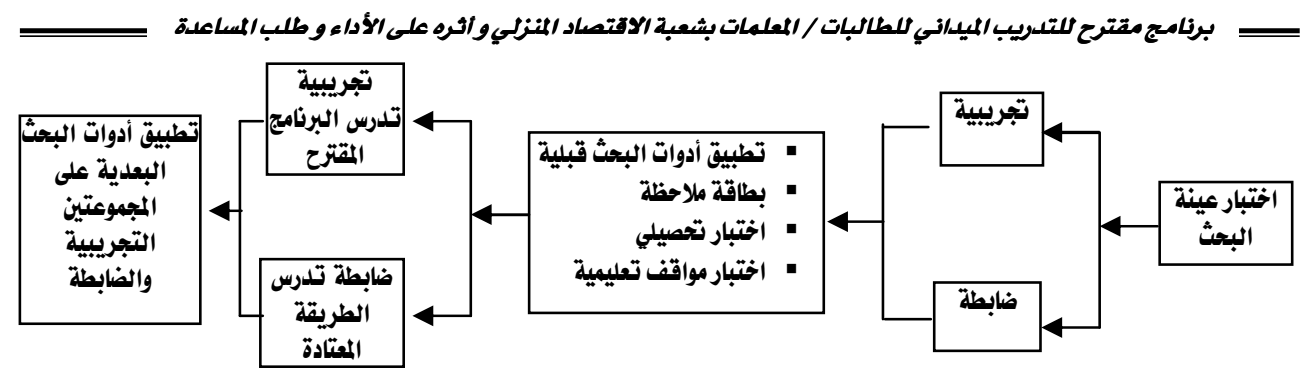

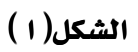

يوضح التصميم التجريبي والقياسي لعينة البحث

فروض البمث :

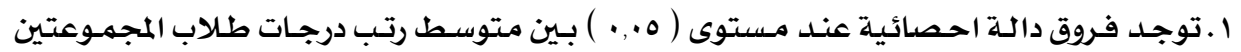

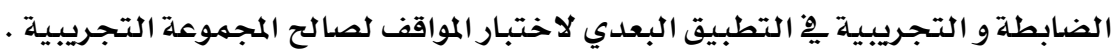

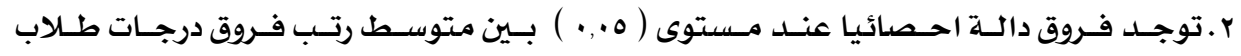

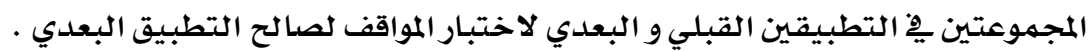

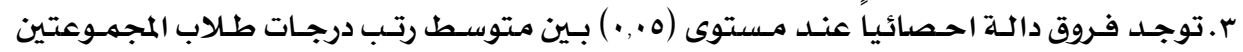

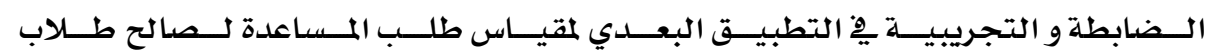

المجموعة الضابطة .

ع. توجد فروق دالة احصائياً عند مستوى ( ه •. • ) بين متوسط رتب فروق درجـات طلاب المجموعة

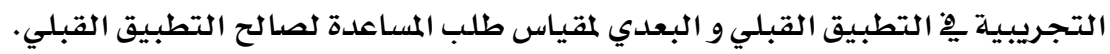

1) فحص الادبيات والدراسات السابقة (العربية والاجنبية) ذات الصلة بمتغيرات البحث

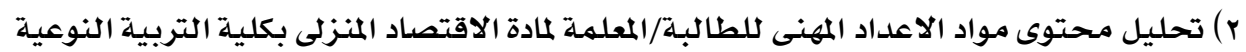

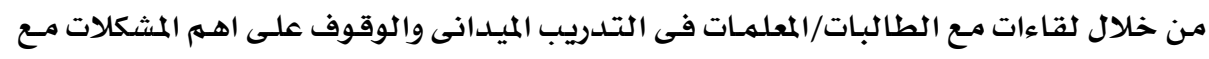

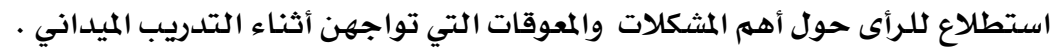

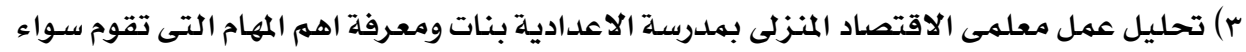

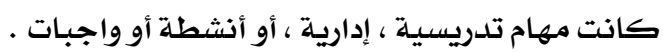

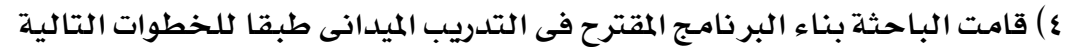

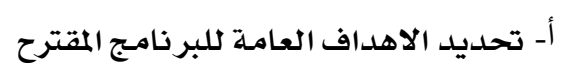$$
\text { ب-تحديد محتوى البرنامـج }
$$

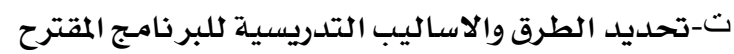

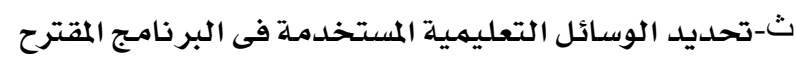

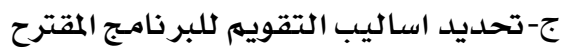

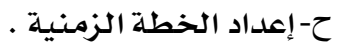




\section{0) الضبط العمهلى للبرناهمج الاقتزةح}

قامـت الباحثة بعـرض البر نامـج المقترح على مجمهوعـة مـن المحكمـين المتخصصـين للتأكس

$$
\text { من صدق البرنامـج من حيث : }
$$

خ-ملائمـة الاهداف العامـة للبر نامـج المقترح

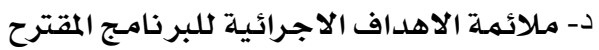

$$
\text { ذ- مـلائمهة مححتوى البرنامـج }
$$

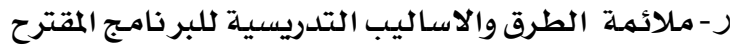

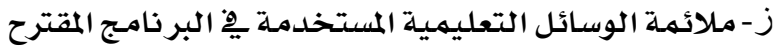

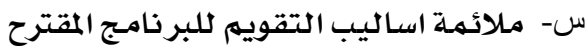

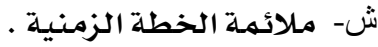

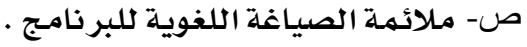

و بعد التعديلات التي أوصى بها المحكمين أصبـح البر نامـج يِّ صورته النهائية و صالح للتطبيق .

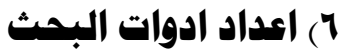

قامت الباحثة ببناء الأدوات اللازمـة لتحقيق أهداف البحث و ضبطها علمياً

أولاً : اختبار مواقف تعليمية لقياس أداء الطالبات / المعلمات عينة البحث . إعلداد الباحثة

الضبط العملي لاختبار المواقف :

ا. قياس الصدق :

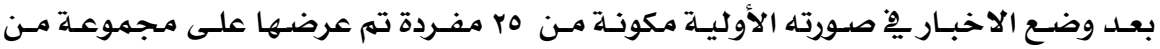

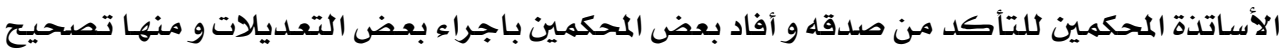

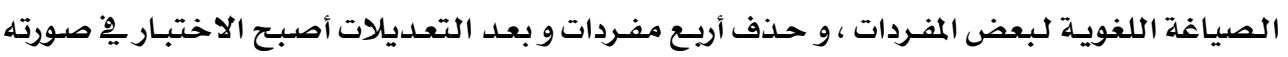

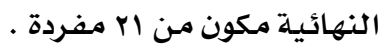

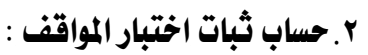

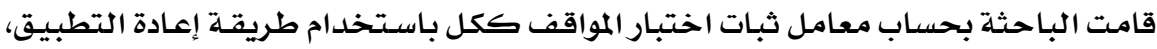

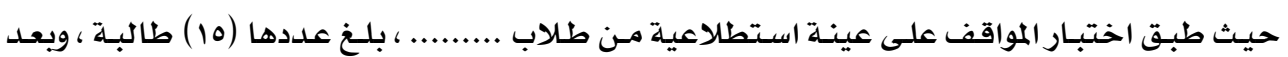

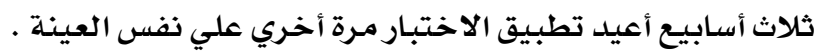
وبعد رصد النتائج وإجراء المعالجة الإحصائية كانت قيمة معامل الثبات كما هي موضحة بالجدول التالي : 


\section{جدول (1)}

معامل ثبات اختبار المواقف ككل بطريقة إعادة التطبيق

\begin{tabular}{|c|c|c|}
\hline مستوي الدلالة & معامل الثبـات & عدد المفردات \\
\hline, .1 &,$\wedge \varepsilon$ & rI \\
\hline
\end{tabular}

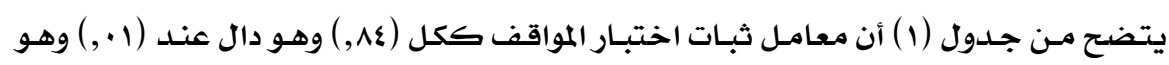

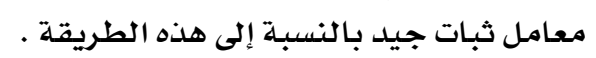

إعداد : أ.د. هانم أبو الخير

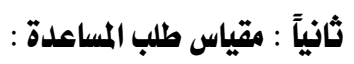
تم الإسـتعانة بمقيـاس طلب المسـاعدة و ذلك لمناسـبته لتحقيق أهـداف البحـث و قد تكـون المقايس من · ع مفردة و قامت الباحثة بالتأكد من ثباته عند تطبيقه على عينة البحث . ا .ثبات مقيـاس طلب المسـاعدة : قامت الباحثة بحسـاب معامـل ثبـات مقيـاس طلب المسـاعدة ككل باستخدام طريقة إعادة التطبيق، حيث طبق مقياس طلب المسـاعدة على عينـة استطلاعيلة مـن

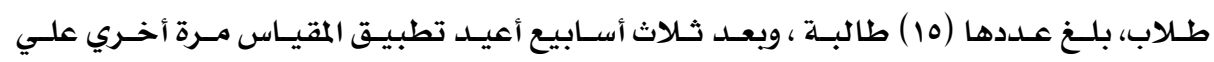

$$
\text { نفس العينـة . }
$$

وبعلد رصد النتائج وإجراء المعالجهة الإحصائية كانت قيمـة معامل الثبات كمها هي موضحة بالجدول التالي :

\begin{tabular}{|c|c|c|}
\hline مستوي الدلالة & معـامل الثبـات & عدد المفردات \\
\hline,$\cdot 1$ &,$\wedge$. & $\varepsilon$. \\
\hline
\end{tabular}

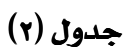

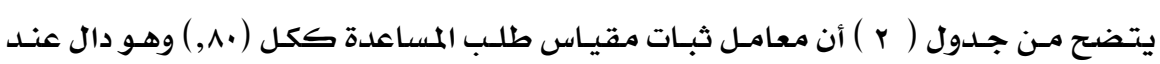
( ا . , ) وهو معامل ثبات جيد بالنسبـة إلى هذه الطريقة

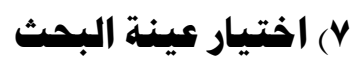

تم اختبـار عينة البـحث من طالبـات الفرقة الثالثة كليـة التربية النوعية و بلـغ عددها مـن ·r طالبـة/معلمهة بشعبـة الاقتصساد المنزلي بـالفرقة الثالثة مقسمة الى مجمهوعـة التجربيـة وتتكون مـن 10

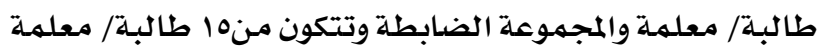
تكافؤ المجموعات : أجرت الباحثة تكافؤ للهمجموعات لكلاً من :

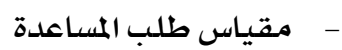
- ماختبار المواقف - 
أ ـ التكافؤ بين الضابطة والتجريبية في اختبار المواقف ككل:

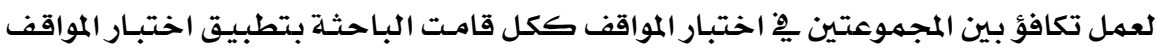

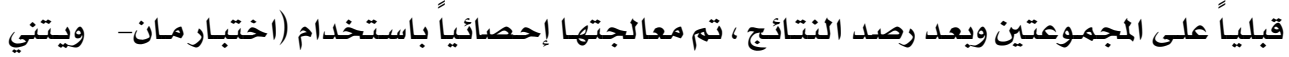
(Mann- Whitney Test

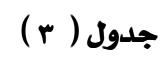

المقارنة قبليإ بين متوسطي رتب درجات طلاب المجموعتين الضابطة والتجريبية فِ اختبار المواقف ككل

\begin{tabular}{|c|c|c|c|c|c|}
\hline مستوي الدلالة & قيمة (u) & مجموع الرتب & متوسط الرتب & علد الطلاب & المجموعة \\
\hline$\cdot, 19$ & \multirow{2}{*}{ AT,O. } & rqr,.• & IV,or & 10 & ضابطة \\
\hline غير دالة & & $r+r, \cdot \cdot$ & Ir, $\{v$ & 10 & تجريبية \\
\hline
\end{tabular}

$$
\text { يتضح من جدول ( r ) : }
$$

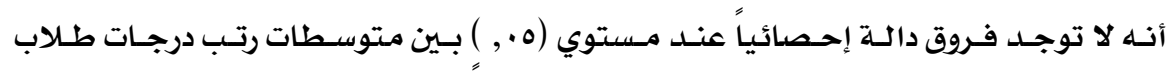

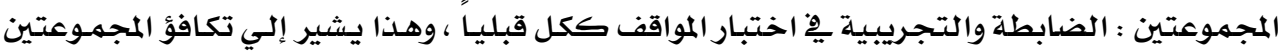

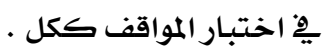

\section{بـ التكافؤ بين الضابطة والتجريبية في طلب المساعدة:}

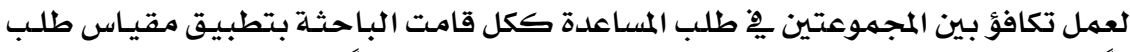

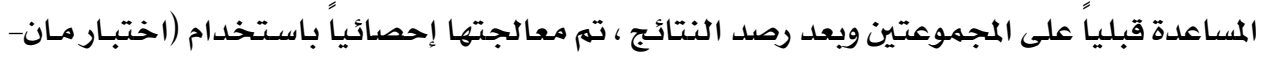

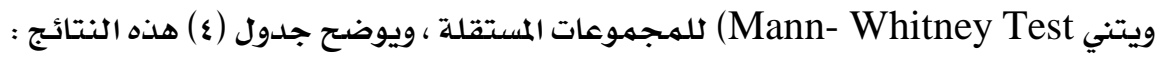

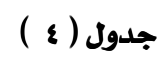

\begin{tabular}{|c|c|c|c|c|c|}
\hline مستوي الدلالة & قيمة (U) & مجموع الرتب & متوسط الرتب & عدد الطلاب & المجموعة \\
\hline$\cdot, r \Lambda$ & \multirow{2}{*}{$\wedge \neg, 0}$. & $r \cdot 7,0$. & $I r, v v$ & 10 & ضابطة \\
\hline غير دالة & & rOA, O. & IV, YY & 10 & تحريبية \\
\hline
\end{tabular}

المقارتة قبلياٍ بين متوسطي رتب درجات طلاب المجموعتين الضابطة والتجريبية ــ مقياس طلب المساعلدة ككل

$$
\text { يتضح من جدول ( ع ) : }
$$

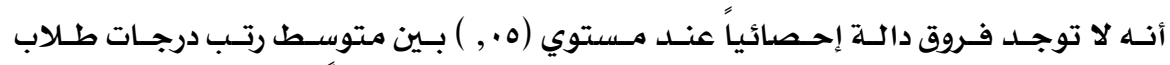

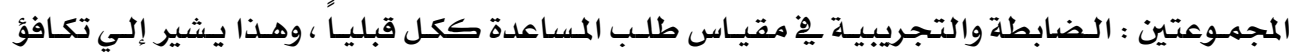

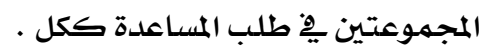

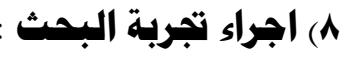
أــ ق قامـت البـاحثة بتطبيتق أدوات البحـث القبليـة على طالبـات عينـة البحث للمجمـوعتين

$$
\text { التجريبية . }
$$


בب ب برنج مقترح للتسريب الميداني للطالبات / المعلمات بشعبة الاقتصاد المنزلمي واثره على الأداء وطلب المساعلة

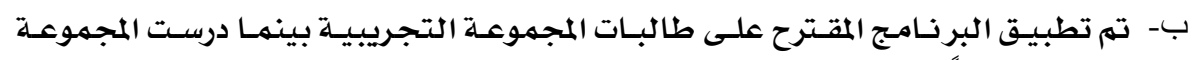

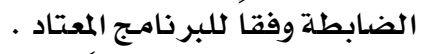

$$
\begin{aligned}
& \text { ت- تطبيق أدوات البـحث بعدياً على المجموعتين . }
\end{aligned}
$$

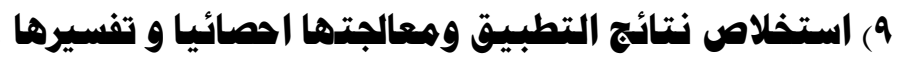

بعـد رصـد نتـائج بـالتطبيق القبلـي و البعـدي تم معالجتهـا احصدائيا و التحقيـق مـن صسحة

$$
\text { فروض البحثث مها يلي : }
$$

\section{• التحقق من صحة الفرض الأول :}

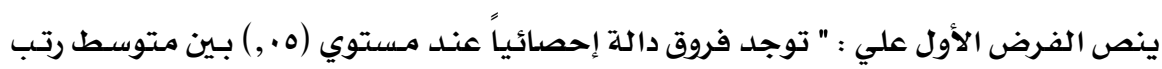

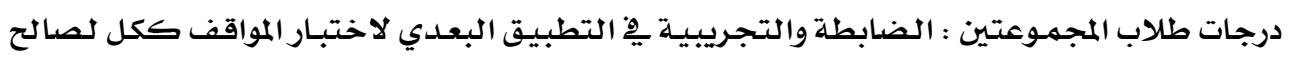

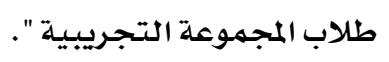

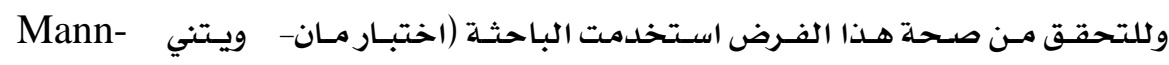
) للمهجموعات المستقلة ، ويوضح جدول ( مhitney Test

$$
\text { جدول ( ) (0) }
$$

\begin{tabular}{|c|c|c|c|c|c|}
\hline مستوي الدلالة & قيمة (U) & مجهوع الرتب & متوسط الرتب & عدد الطلاب & المجموعة \\
\hline \multirow{2}{*}{,+1} & \multirow{2}{*}{$\xi, \bullet$} & IrE,." & $\Lambda, r V$ & 10 & ضابطة \\
\hline & & rßl, $\cdot \bullet$ & $r r, r r$ & 10 & تجريبية \\
\hline
\end{tabular}

المقارنة بين متتوسطات رتب درجات طلاب المجموعتين : الضابطة والتجريبية

20تو التطبيق البعدي لاختبار المواقف ككل

يتضح من جدول ( ه ) ما يلي :

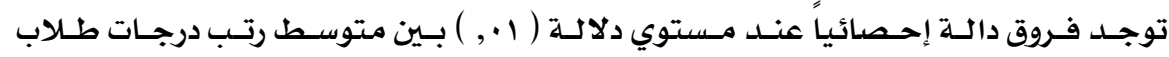

المجموعتين : الضـابطة والتجريبية يِّ التطبيق البعدي لاختبار المواقف ككل لصالح طلاب المجموعة

التجريبية.

وتدل هذه النتائج علي تحقق الفرض الأول من فروض البـحـ ، ويهكن تفسير النتائج علي

النحو التاني:

تفوق المجموعة التجريبية يخ التطبيق البعدي و قلة طلب المسـاعدة و ذلك برجـع للبرنامـج

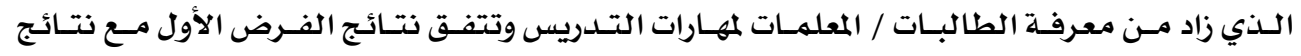

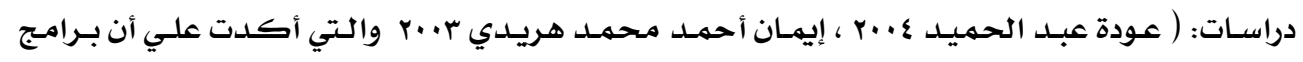
اعداد المعلم تزيد من الكفاءة المهنية للمتدريسين . 


\section{• التحقق من صحة الفرض الثاني:}

ينص الفرض الثاني علي : " توجد فروق دالة إحصائياً عند مستوي (ه . ,) بين متوسط رتب التب

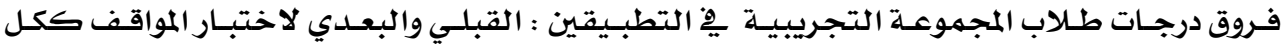

$$
\text { لصالح التطبيق البعدي ". }
$$

وللتحقق من صحة هذا الفرض استخدمت الباحثة (اختبـارولكوكسن - إشـارة الرتب (Wilcoxon - Signed Ranks Test

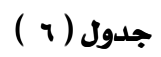

\begin{tabular}{|c|c|c|c|c|c|}
\hline \multicolumn{6}{|c|}{ لاختبار المواقف ككل } \\
\hline مستوي الدلالة & قيمة (Z) & مجهوع الرتب & متوسط الرتب & ن & الرتب \\
\hline \multirow{2}{*}{,+1} & \multirow{2}{*}{ r,ZrY_ } & صفر & صفر & صفر & السالبة (و-) \\
\hline & & Ir.,.* & $\Lambda, \cdot \cdot$ & 10 & الموجبة (و+) \\
\hline
\end{tabular}

المقارنة بين متوسطات رتب فروق درجات طلاب المجموعة التجريبية ـي التطبيقين : القبلي والبعدي

$$
\text { يتضح من جدول ( r ج ) ما يلي : }
$$

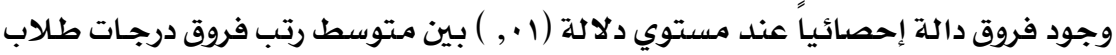

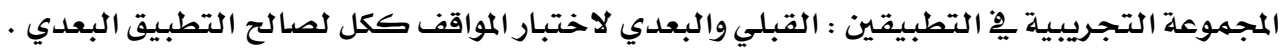
وتدل هذه النتائج علي تحقق الفرض الثاني مـن فروض البحتث ، ويمكن تفسير النتائج

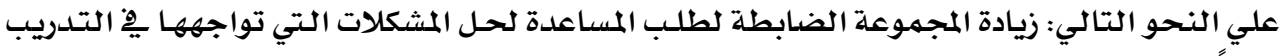

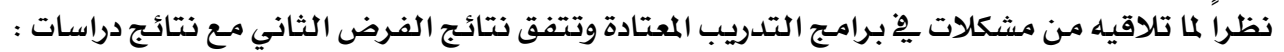

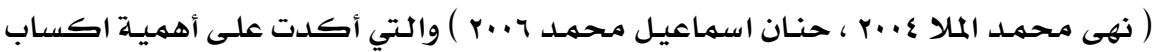

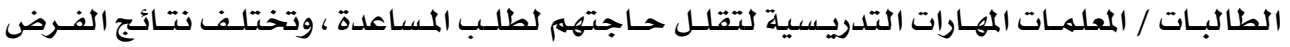

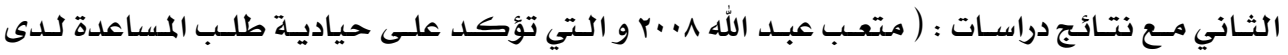
الطلاب / المعلمـين

قياس أثر البرنامج المقترح فى تنمية أداء الطالبات المعلمات فِ التدريب الميداني ككل :

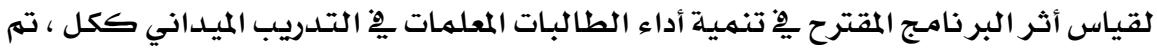

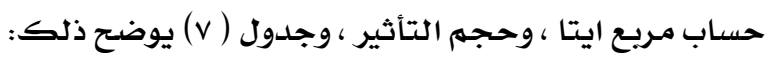

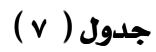

حجم تأثير البر نامـج المقترح ـِ تنمية أداء الطالبات المعلمات فِ التدريب الميداني ككل

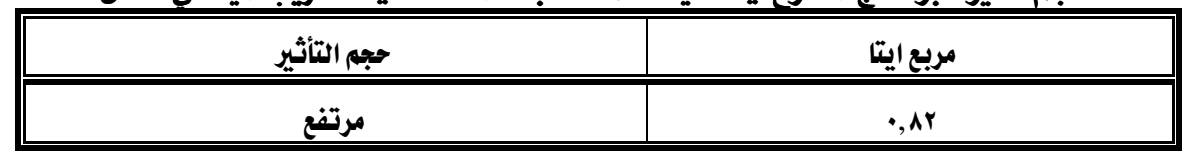




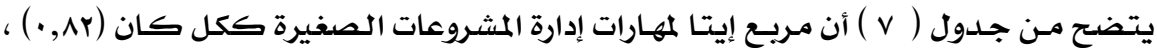

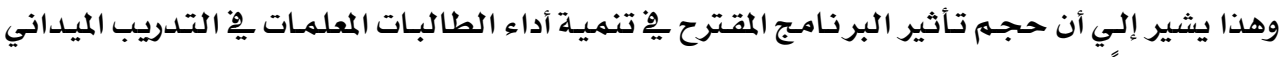

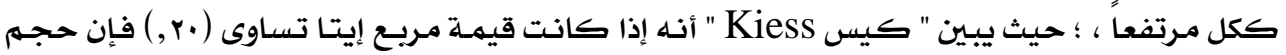

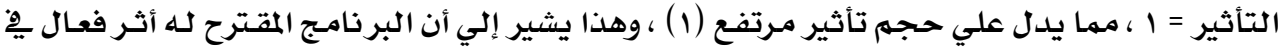

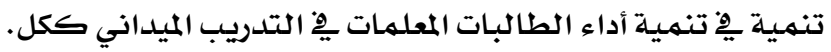
وبذلك تكون الباحثة قد أجابت عن السؤال ... من أسئلة البحث والذي ينص علي " مـا أثر

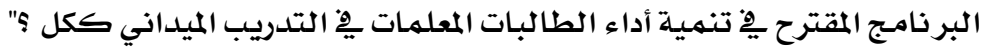

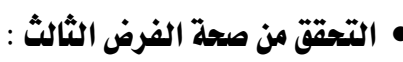

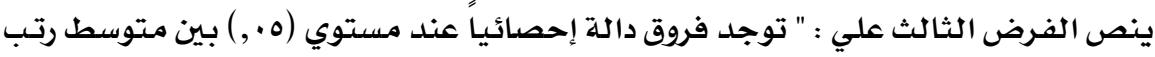

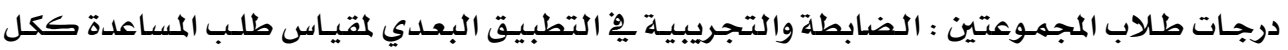
لصالح طلاب المجموعة الضابطة ".

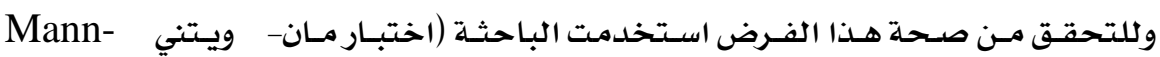
(Whitney Test

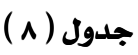

المقارنة بين متوسطات رتب درجات طلاب المجموعتين : الضابطة والتجريبية يو التطبيق البعدي لمقياس طلب المساعدة

\begin{tabular}{|c|c|c|c|c|c|}
\hline مستوي الدلالة & قيمة (u) & مجموع الرتب & متوسط الرتب & عدد الطلاب & المجموعة \\
\hline \multirow{2}{*}{,+1} & \multirow{2}{*}{$v, \cdot \bullet$} & rrA, , & rr,or & 10 & ضابطة \\
\hline & & IrV,.• & $\Lambda,\{\vee$ & 10 & تجريبية \\
\hline
\end{tabular}

$$
\text { يتضح من جدول (^) ما يلي : }
$$

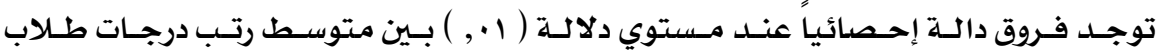

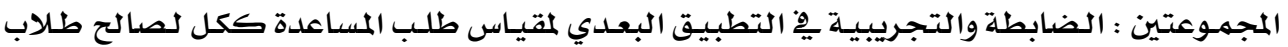

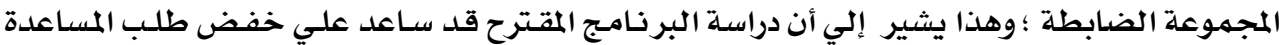
لدي طلاب المجموعة التجريبية. وتدل هذه النتائج علي تحقق الفرض الثالث من فروض البحث ، ويمكن تفسير النتائج علي

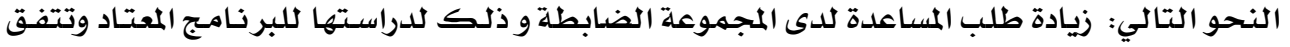

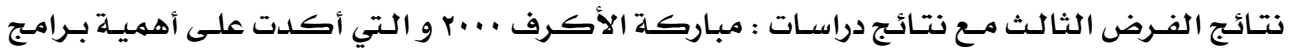

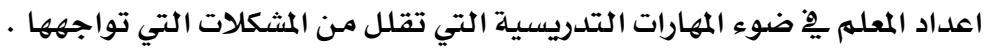

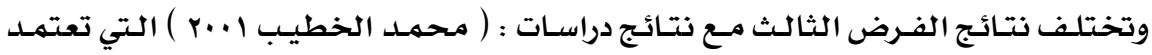

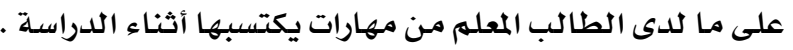




\section{• التحقق من صحة الفرض الرابع:}

ينص الفـرض الرابـع علـي : " توجـد فروق دالـة إحصـائياً عند مستوي (ه . , ) بـين متوسطات

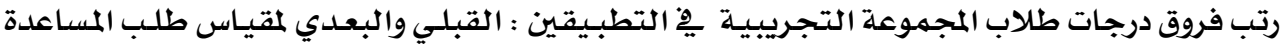
ككل لصالح التطبيق القبلي ".

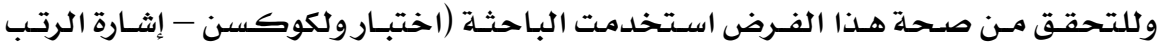
) Wilcoxon - Signed Ranks Test

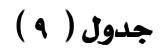

المقارنة بين متوسطات رتب فروق درجات طلاب المجموعة التجريبية يِ التطبيقين : القبلي والبعدي لمقياس طلب المساعدة ككل

\begin{tabular}{|c|c|c|c|c|c|}
\hline مستوي الدلالة & قيمة (Z) & مجموع الرتب & متوسط الرتب & j & الرتب \\
\hline \multirow{2}{*}{,+1} & \multirow{2}{*}{$r, \xi \cdot \Lambda$} & Ir.,.* & $\Lambda, \cdot \cdot$ & 10 & السالبة (و-) \\
\hline & & صفر & صفر & صفر & الموجبة (و+) \\
\hline
\end{tabular}

$$
\text { يتضح من جدول ( } 9 \text { ) ) ما يلي : }
$$

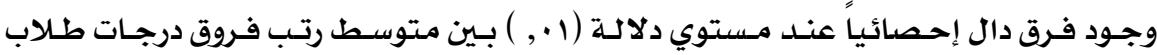

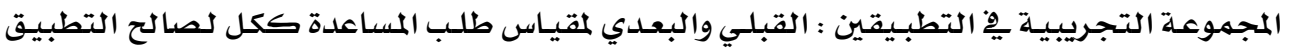

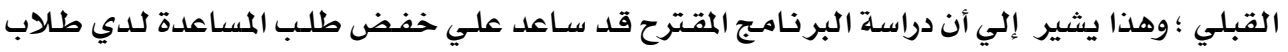

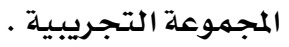

وتدل هذه النتائج علي تحقق الفرض الرابع من فروض البحث ، ويمكن تفسير النتائج علي

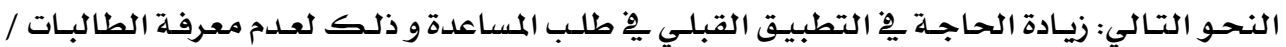

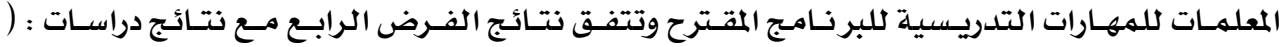

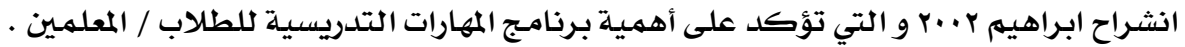
قياس أثر البر نامجح المقترح فِ خفض طلب المساعدة ككل للدي الطالبيات المعلمات ف2 التدريب الميداني:

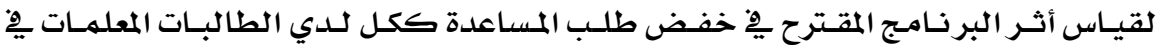

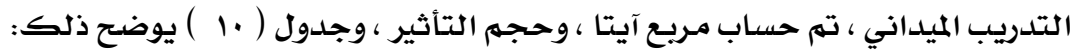

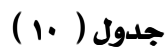

\begin{tabular}{|c|c|}
\hline حجم التأثر & مربع آيتا \\
\hline مرتفع & $\cdot, A r$ \\
\hline
\end{tabular}

حجم تأثير البرنامبج المقترح ِِّ خفض طلب المساعدة لدي الطالبات المعلمات ِِ التدريب الميداني ككل

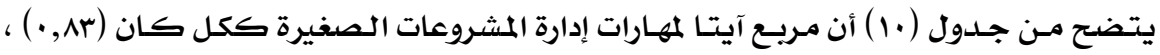

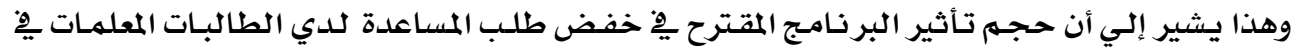




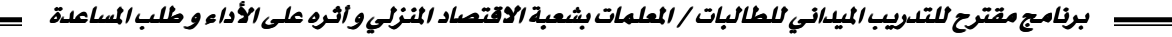

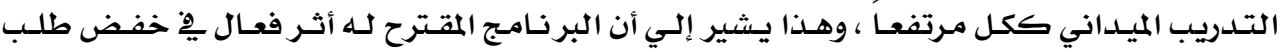

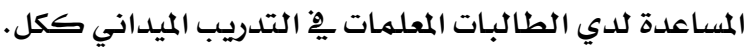

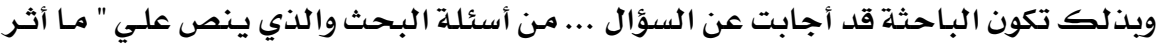

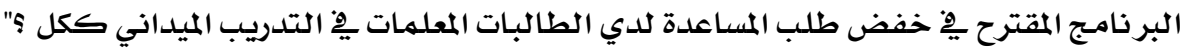

تعقيب عام على النتائج :

من النتائج السابقة يتضح ما يلي :

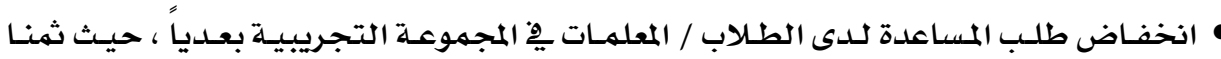

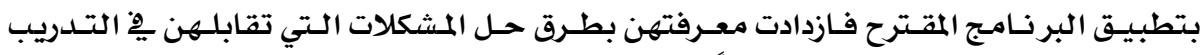

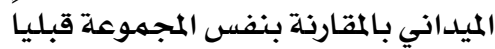

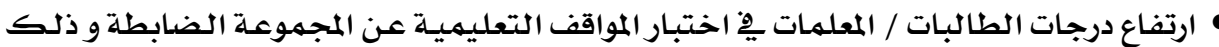

لمعرفة الطالبات المعلمات للمهارات التدريسية من خلال البرنامج التدريبي المقترح .

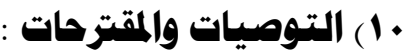

• تطبيق مقياس طلب المساعدة على مراحل تعليمية مختلفة

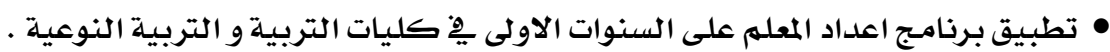

الأساس النظري للبحث :

• مفهـوم التــريب الميـدانى واهــاف التـدريب الميـداني واسـس ومبـادى التـدريب الميـدانى واهميـلة

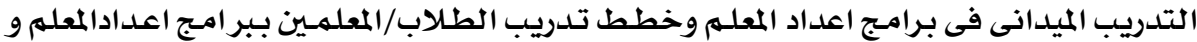

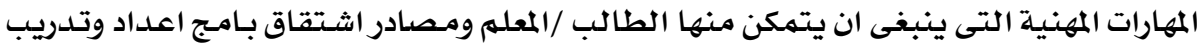

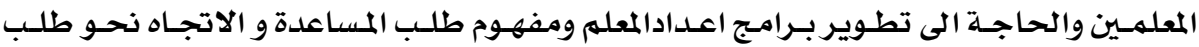

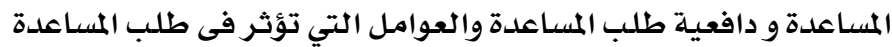

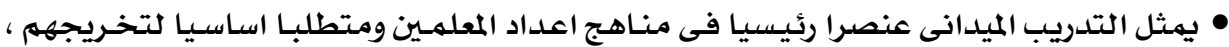
وهى كذلك تحسلد مرحلة تحضيرية حاسمة يتوقف على نوعية خبر اتها وعلاقات المشتركين

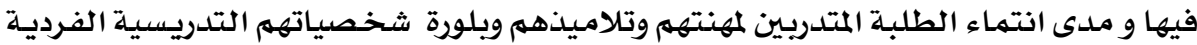

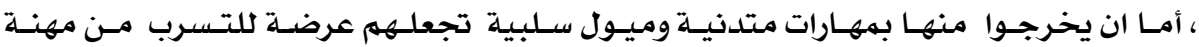

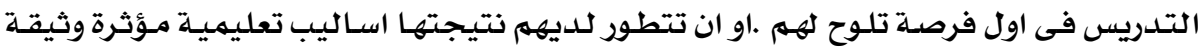

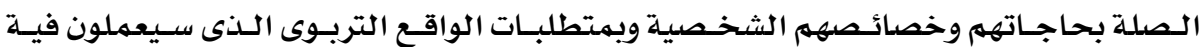
ويجدر التأكيد هنا بانة حتى يتسنى لطلبة المتدربين تحقيق ما يصبون الية من ميول ايجابية

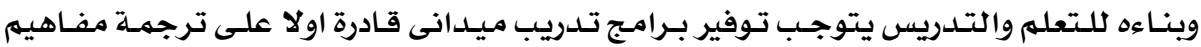

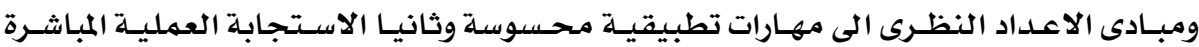

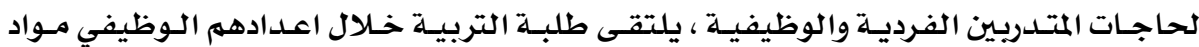

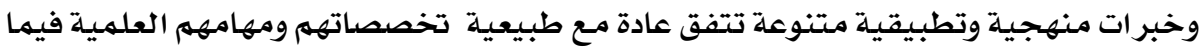




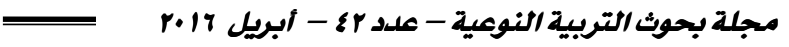

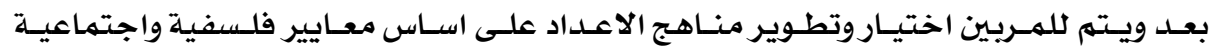

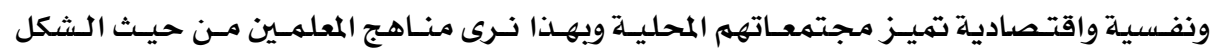

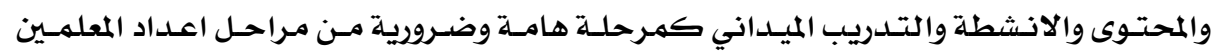

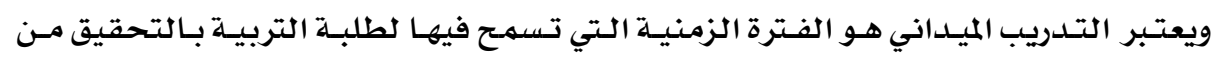

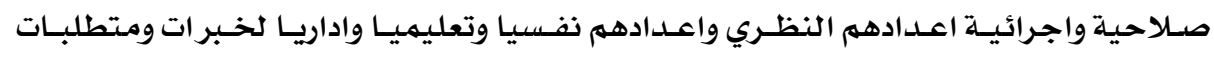

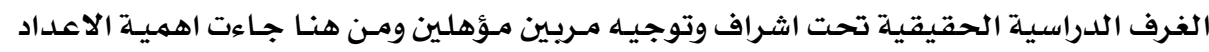

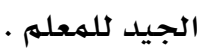

ولقد افادت الدراسـات المنهجية الشـاملة لبر امـج اعداد المعلمـين بـان العناصـر الاسـاسيـة لهـدا

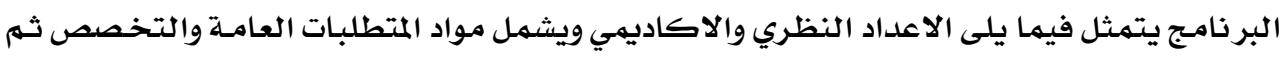

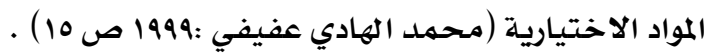

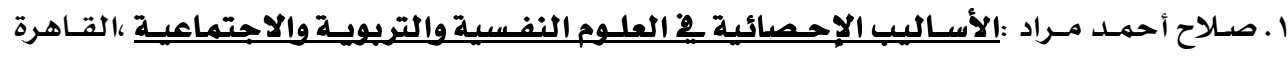

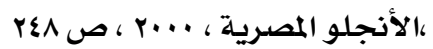




\section{Study summary:}

1) examination of the literature and previous studies (Arab and foreign) the relevant variables Search

2) content preparation for vocational student / teacher of a substance Home Economics Faculty of Specific Education materials analysis

Through interviews with the students / teachers in the training field and stand on the most important problems with the poll on the most important problems and obstacles that Tusbandn during field training.

3) analysis of the work of teachers of Home Economics, junior high school girls and find out the most important tasks is whether the functions of teaching, administrative, or activities or duties.

4) The researcher proposed building program in the field training according to the following steps

- determining the general objectives of the proposed program

- determine the content of the program

- determine the ways and methods of teaching the proposed program

- determine the educational methods used in the proposed program

- determine the methods of evaluation of the proposed program

- preparation time plan.

5) setting practical for the proposed program

The researcher presented the proposed program at a group of arbitrators specialists to ensure the veracity of the program in terms of:

- Appropriate general objectives of the proposed program G.

- Appropriate procedural objectives of the proposed program d.

- appropriate program content

- appropriate ways and methods of teaching the proposed program

- appropriate teaching aids used in the proposed program

- appropriate methods of evaluation of the proposed program KSC appropriate time plan.

- appropriate the language of the program.

After the amendments recommended by the arbitrators, the program has become in its final form and in favor of the application.

6) the development of tools Search

The researcher to build the tools necessary to achieve the objectives of the research and scientifically tuned 